\title{
Viewpoints of Quran on Euthanasia and Assisted- Suicide
}

\author{
Mahmood Atharizadeh \\ Department of English Language, Kashan University of Medical Sciences \\ PO Box: 8715973674, BLVD Qutb Ravandi \\ Kashan, Iran \\ Tel: 009-855-540-021 E-mail: m.atharizadeh@ yahoo.com
}

Received: November 25, 2019 Accepted: December 14, 2019 Published: April 20, 2020

doi:10.5296/iss.v8i1.16909ＵRL: http://dx.doi.org/10.5296/iss.v8i1.16909

\begin{abstract}
Euthanasia is a new phenomenon which emerges in medical fields and it may become the process of entering in common use, though, it has undergone a long history with sharp ethical, legal, and philosophical controversies among philosophers and theologians. In addition, it may cause arguments for and against its use among physicians in treating gravely ill patients suffering from terminally dead diseases. Therefore, some governments try to legalize it in their parliaments. Although it may be considered as a new good alternative for treating such patients, there is no single criterion for its applying. Quran, the Book of Islam, sharply rejects and forbids euthanasia and considers it an action against the will of God and the purpose of human being's creation which deserves an eternally punishment in the after world.
\end{abstract}

Keywords: Euthanasia, Quran, Illegalization, Controversies, Assisted-suicide 


\section{Introduction}

Science is like a never ending flow of river. It keeps on updating, renovating and reinventing itself every moment and delights us with new sophisticated technology which provides us the options which never existed before. However, the new technologies have spawned new ethical concerns which attracted wide medical attention and public debate (Bilal \& Badr, 2013).

Euthanasia is one of the issues that have been the subject of intense debate over time. It has been a pertinent issue in human rights discourse as it also affects ethical and legal issues pertaining to patients, their relatives and health care providers (Bilal \& Badr, 2013).

The word Euthanasia comes from the Greek - "Euthanatos" derived from the words 'eu' meaning good and 'thanatos' meaning death. It has been defined as - mercy killing of the hopelessly ill, injured or incapacitated (Translation of Sahih Muslim).

Normally - Euthanasia is defined as gentle and easy death: bringing of this especially in the case of incurable and painful diseases. In fact, pain and sufferings in the way of dying is a more terrible word of mankind than even death itself. Here, it can be said "It is not death one fears to face, but dying". It means that one does not fear to face the darkness of death but fears to go through the sufferings (Nargus, 2012). Euthanasia in all of its forms- whether voluntary, involuntary, passive, active and physician assisted suicide- is considered a highly controversial subject which arises many dilemma as well as questions in mind particularly among medical groups and caregivers. The common question may be: Is not a prudent to legalize euthanasia for performing it to patients suffering from terminally dead diseases and provide them a dignified death? What about patients who are in constant vegetative state or in comma and will probably never recover consciousness so they burden many medical costs on society (Nargus, 2012)?

From a legal point of view, the family has no part in the decision-making process (PMCID: PMC5300707). The simple view is that a family asks for an end to life because the family does not want their beloved one to suffer any longer. (Geritt \& Psychiatry, 2017) There are some ancient documents making explicit the illegality of killing gravely ill patients suffering from terminally dead diseases. Such as other terms i.e. abortion, IVF, surrogate, it poses many dilemmas and controversies among lawmakers, philosophers, physicians, and theologians. So, some countries attempt to legalize it in their parliaments to solve painful terminally dead diseases and to make easily health care decisions. Since it infringes God's Will and Actions, human's inherent values, and existential facts as well as social sacredness, its Quranic survey is significant. Here for brief, we limit our discussion on Quran insights concerning the unlawfulness of euthanasia.

Moreover, there is broad consensus across religious beliefs that it is wrong to kill an innocent human being. It is usually stated there is an inherent sanctity about all human life as each life belongs to God (Darmian, 2009).

Killing of the innocent, suicide and euthanasia have been considered deserving of moral opprobrium. This position has been well documented by the scholastic philosopher Thomas 


\section{Macrothink}

Aquinas. He condemned suicide for the following reasons.

- It violates one's natural desire to live.

- It harms other people.

- Life is the gift of God and is therefore only to be taken by God. Suicide, Augustine determined, was an unrepeatable sin. St. Thomas Aquinas later defended this prohibition on three grounds. (Abu \& Isma'il, 2016) Suicide is contrary to natural self-love, whose aim is to preserve us. (Bible) Suicide injures the community of which an individual is a part. (Bilal \& Badr, 2013) Suicide violates our duty to God because God has given us life as a gift and in taking our lives we violate His right to determine the duration of our earthly existence (Standford Encyclopedia of Philosophy).

This conclusion was codified in the medieval doctrine that suicide nullified human beings' relationship to God, for our control over our body was limited to usus (possession, employment) where God retained dominium (dominion, authority). Law and popular practice in the Middle Ages sanctioned the desecration of the suicidal corpse, along with confiscation of the individual's property and denial of Christian burial (Standford Encyclopedia of Philosophy).

According to the theology of the Roman Catholic Church, suicide is objectively a sin which violates the commandment "Thou shalt not kill".

\section{Methodology}

Some scientific articles and Islamic texts were reviewed to prove the illegalization of performing euthanasia on gravely ill patients suffering from terminally dead diseases and forbiddance of committing suicide by human beings.

\section{Literature Review}

\subsection{History of Euthanasia}

The history of euthanasia dates back to ancient Greece. In ancient Greece and Rome, before the coming of Christianity, attitudes toward infanticide, active euthanasia, and suicide had tended to be tolerant. Many ancient Greeks and Romans had no cogently defined belief in the inherent value of individual human life, and pagan physicians likely performed frequent abortions as well as both voluntary and involuntary mercy killings. The traditional Hippocratic Oath was explicit that the role of a physician was to preserve human life and not to be instrumental in its destruction.1-3 The oath stated 'To please no one will I prescribe a deadly drug nor give advice which may cause his death. (PMCID: PMC5300707)' 'Primum non nocere' is another famous adage that warns doctors at all costs not to harm their patients. These traditional concepts are opposed to the killing of a human being. Traditional Abrahamic religious teaching states that it is wrong to kill the innocent. However the advances in medical care have created new situations (Geritt \& Psychiatry, 2017).

Although the Hippocratic Oath prohibited doctors from giving 'a deadly drug to anybody, not even if asked for,' or from suggesting such a course of action, few ancient Greek or Roman 
physicians followed the oath faithfully. Throughout classical antiquity, there was widespread support for voluntary death as opposed to prolonged agony, and physicians complied by often giving their patients the poisons they requested" (Darmian, 2009).

\subsection{Prohibition of Euthanasia in Hippocratic Oath}

Ending human life whether a patient suffering a deadly disease demands or his/her relatives is forbidden in Hippocratic Oath. As stated in the Oath, Hippo crate swears that he will neither give a deadly drug to anybody if asked for it, nor will he make a suggestion to this effect.

I will use treatment to help the sick according to my ability and judgment, but never with a view to injury and wrong-doing. Neither will I administer a poison to anybody when asked to do so, nor will I suggest such a course. Similarly I will not give to a woman a pessary to cause abortion. But I will keep pure and holy both my life and my art. I will not use the knife, not even, verily, on sufferers from stone, but I will give place to such as are craftsmen therein (McMaster University).

\subsection{Factors Involving in Committing Euthanasia}

Many factors are involved in committing or accepting euthanasia which persuade patients suffering from terminally and deadly illness to accept it willingly. Determinative factors are: social isolation, loss of physical integrity, fear of becoming a burden, cumulative life stressors, and an increased number of losses of friends and family members, serious medical illness (cancer or cardiovascular disease) and some form of depression preceding death. sadness over loss of quality of life and loss of autonomy (Geritt \& Psychiatry, 2017).

For instance, some patients not only felt that they were a burden to society, but also blamed society for spending a substantial amount of money on keeping patients with a wish to die alive when they felt that this money could be better spent if society would instead concentrate on helping those people who want to live. In fact, some felt that this amounted to preventing lives being saved - of those who wished to live - as those who wished to die would be willing to donate their organs to save the lives of others. Third, additional aspects of suffering, for example, the experience of solitude or loneliness because of a lack of social support from 'society in general', were reported. This kind of social isolation 'by choice' sometimes resulted from the (perceived) experience of being socially or emotionally isolated from others or removed from society. Some patients spent excessive time alone at home, not allowing visits from others and avoiding any kind of meaningful contact with relatives, friends or acquaintances. Instead, these patients severely restricted such contact to limited, superficial or accidental meetings with neighbors. This can be distinguished from unwanted social isolation, where, for example, patients regretfully described not having relatives or friends anymore because of the (symptoms of their) illness, or because their relatives were living abroad (Geritt \& Psychiatry, 2017).

\subsection{Euthanasia and Free Will}

Free will is the ability to choose between different possible courses of action unimpeded. 


\section{Mll Macrothink}

It is closely linked to the concepts of moral responsibility, praise, guilt, sin, and other judgments which apply only to actions that are freely chosen. It is also connected with the concepts of advice, persuasion, deliberation, and prohibition (Jesse, 2015).

The term "free will" has emerged over the past two millennia as the canonical designator for a significant kind of control over one's actions.

It has been taken up in every period of Western philosophy and by many of the most important philosophical figures, such as Plato, Aristotle, Augustine, Aquinas, Descartes, and Kant (Micheal, 1961).

Advocates of euthanasia argue that people have free will and a right to make their own decisions regarding death, and that euthanasia is intended to alleviate pain and suffering. Furthermore, it is said that good palliative care can provide relief from suffering to patients and unlike euthanasia, should be the answer in modern medicine (McMaster University).

\subsection{Individual Ownership Rights}

According to existentialism, human beings, through their own consciousness, create their own values and determine a meaning to their life. (Jesse, 2015) Man is an owner of his taught, actions, life and existence and will. He has the rights to choose, determine, and act under no super power. Therefore, he has an individual right in determining how to live and to end his life (Nargus, 2012).

Therefore, the right to lose health, become ill, refuse treatment, live the end of life according to one's personal view of life, and die should be guaranteed, which is in keeping with human dignity and the duty to protect physical and mental health (PMCID: PMC5300707).

On the other hand, an opposite view states that life is a unique and incorruptible gift that, in keeping with the concept of the sanctity of human life, must always be preserved. Hence, each individual has the moral duty to attend to all the treatment necessary to preserve life, with the exception of those burdensome and/or disproportionate to the hoped for or expected result (i.e., life preservation), and to avoid behaviors that can deliberately hasten or cause death (PMCID: PMC5300707).

\section{Islam and the Entity of Human Being}

\subsection{Man Is Composed of Spirit, Soul, and Body}

Despite of other creature, the existence of man is immaterial and eternal. It is composed of three main parts: spirit ,soul, and body which are basically different. Usually, no one may consider all of them as the same realities. They can easily distinguish the body and its characteristics from two other parts but may consider the spirit and the soul as the same. What can be understood from celestial and sacred books such as the Bible and Quran leads us to this fact that spirit, soul, and body are three fundamental aspects of human being.

"And the God of peace Himself sanctify you wholly, and may your spirit and soul and body be preserved complete..." (Bible). 


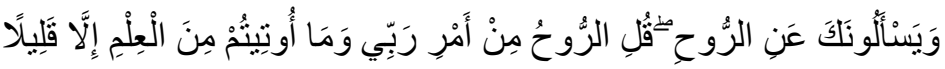

"They will ask you about the spirit. Say:" The spirit (operates) at may lord's while you have been given only a smattering of knowledge"(16, 17:85).

It is not asked about the "soul". So, it can be implied that there is a difference between "spirit" and "soul". In another verse The "soul" is blamed but ther is no verse in Quran to blame the "spirit".

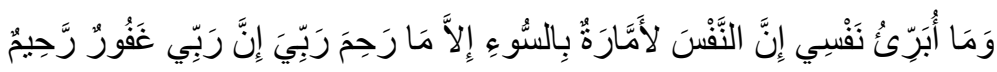

And I do not acquit myself. Indeed, the soul is a persistent enjoiner of evil, except those upon which my Lord has mercy. Indeed, my Lord is Forgiving and Merciful"(16, 12:5).

\section{Islam and Free Will}

Although man is born free and has free will to determine his destination by himself, the real owner of existence, which constitute his reality and destination, is God. Therefore he can not use it according to his free will. In fact, existence is a Divine Gift bestowed to man to be used according to God's will." Man is born free and everywhere he is in chain (Standford Encyclopedia of Philosophy).

\section{Islam and Ownership Rights}

Although ownership rights is accepted among man during the history and there is an accepted general consent emphasizing that man has an ownership on his privacies and properties, the real ownership of existence is God. In fact and according to Quranic verses, God creates man and bestows him his existence which is the most valuable thing that nothing can be compared with it .He is the Real Ownership of the creature system and due to His connection to creatures' their beings are accessible. Socially and accordance to human custom, it is obvious that interference with others' ownership without their consents is considered immoral and illegal. And since Spirit and Existence belong to God not human being, human being is not allowed to interfere in them and is not permitted to end his life whenever he wishes.God has bestowed the man a type of ownership which is not a real one but a subsidiary ownership on his properties and privacies which are practical and valuable during his lifetime. In fact, man has no domain on his existence because he has not created himself and has no ownership on his existence. If man had such domain and ownership, he would be able to save, keep, and manage it whenever he wishes and live for a long time and be eternal but, in fact, we see that the life of human being is limited. Therefore, God is the real creator and bestow the existence to creatures and phenomena as a precious gem, then, man is merely capable to interfere in his existence only under the permission of God.

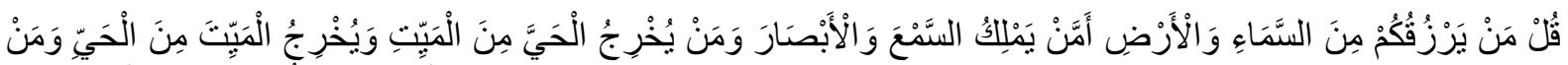

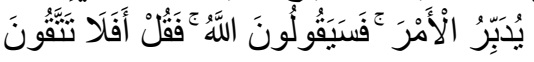

Say, "Who provides for you from the heaven and the earth? Or who controls hearing and sight and who brings the living out of the dead and brings the dead out of the living and who arranges [every] matter?" They will say, "Allah," so 
say, "Then will you not fear Him"(16, 10:31).

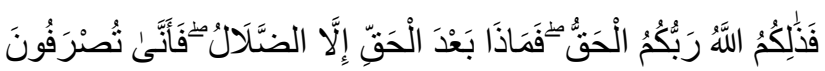

For that is Allah, your Lord, the Truth. And what can be beyond truth except error? So how are you averted (16,10:32)?

\section{Prohibition of Manslaughter in Islam}

Existence and essence are the first and biggest Divine Blessing God bestow to human being in order to develop and promote to be able to reach his ultimate goal which is his eternal felicity. And since the real value of human concerned with existence without it the body has no value and destiny but deterioration and destruction and the real creature and owner of existence is God, killing and destroying it is considered a big and unforgiveable sin its doer will be heavily punished. Consequently and according to Quran, killing oneself or one another, suicide, and euthanasia all of them are condemned and who commits them (their murder) will undergoes an eternal perdition.

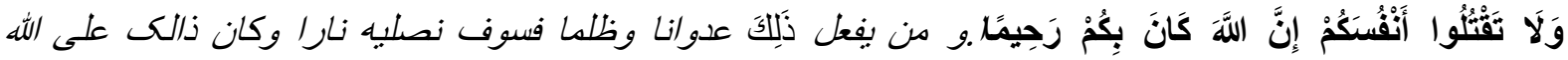
I.And do not kill one another and whoever does this aggressively and unjustly, we will soon cast him into fire; and this is easy to Allah (16, 4:29-30). This verse apparently interdicts suicide and killing another. In fact, God is not only dissatisfied that another kills you, but also does not permits you to commit suicide willingly. Of course, this is completely different from sacrificing for saving the Islam and Divine ideals and God's sake which are admired and will be rewarded.

\section{Prohibition of Euthanasia}

Euthanasia is not exceptional from Divine commands. According to Quran and Islamic teachings, it is certainly prohibited and forbidden. Since God is the creature of living and death,

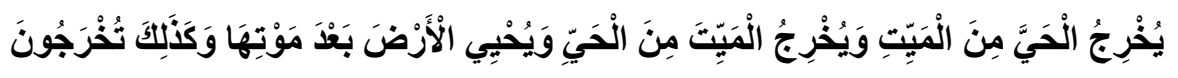

He brings forth the living from the dead and brings forth the dead from the living, and he revives the earth following its death. Thus shall you be brought forth 16, 30:19.) Therefore, tacking away the life of a terminally painful and incurable patient by his/ her own decision or by his family or others is an illegal action and interfering in God's will.

\section{Euthanasia and Willing of Self-Sacrifice}

Of course, euthanasia is certainly different from sacrificing or being killing oneself for God's sake which are adorable and their actions are rewarded as God's bounty. "Do not kill or take a human life which God has declared to be sacred" (16, 6:151).

The suffering of death on account of adherence to a cause and especially to one's religious faith, is prescribed and authorized in Quranic doctrine

In Islam the act of sacrifice is the symbol of a Muslim's readiness to lay down his life, and to sacrifice all his interests and desires in the cause of truth (Translation of Sahih Muslim). 


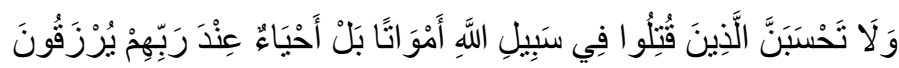

"Do not reckon those who are killed for God's sake are dead, but rather\{ they are\} living; they will be provided for by their Lord.(16,3:169)

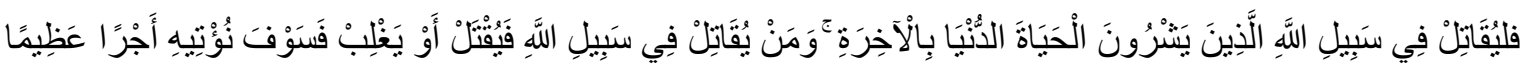

"Let those who barter worldly life for the Hereafter fight for God's sake; we shall pay a splendid fee to anyone who fight in god's way, and is either killed or is victorious" (16,4:74).

\section{Euthanasia and Martyrdom (Shahid)}

Martyrdom definition is - the suffering of death on account of adherence to a cause and especially to one's religious faith (Merriam-webster.com).

The word shahid (plural shahada) has the meaning of "martyr" and is closely related in its development to the Greek martyrios in that it means both a witness and a martyr (i.e., a person who suffers or dies deliberately for the sake of affirming the truth of a belief system). Although shahid in the first sense occurs frequently in the Quran, in the latter sense only once is it attested (13:141). In the Hadith literature, and most especially in the subset of the jihad literature that was parallel to it, the term is frequently used, and it gradually makes an appearance in the historical and literary texts as well. Martyrdom in Sunni Islam, other than the very earliest period of persecution by the polytheists of Mecca, has been closely associated with death in battle. Other forms of death or suffering, such as enduring plagues, suffering persecution for theological issues (the mihna, 833-861 CE, for example), and a wide range of other less-accepted circumstances have also been considered to generate martyrdom. In general, the attitude of the Sunni Muslim toward martyrdom has been a positive one, and inside the literature on martyrdom there are rewards that are specific to the martyr as opposed to other Muslims (Merriam-webster.com).

According to Quran, book of Islam, traditions and other Islamic teachings, people who die fighting against injustice, tyranny, and infidelity are believed to have a sacred and virtuous action and to be attained martyrdom and rewarded by their Lord. However, they who commit suicide and accept euthanasia for ridding themselves of any suffering or deadly painful disease will undergo a painful perdition in the afterward.

\section{Quran and Suicide}

The reality of giving life and taking life belong to God.

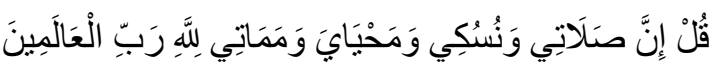

"Say: Truly, my prayer and my service of sacrifice, and my living and my dying are for God (alone) (1,6:162).

Their times are destined in God's Knowledge and Commands. Therefore, no one is permitted to take his life intentionally or unintentionally because it is an infringement to God's willing and His Commands (Translation of Sahih Muslim).

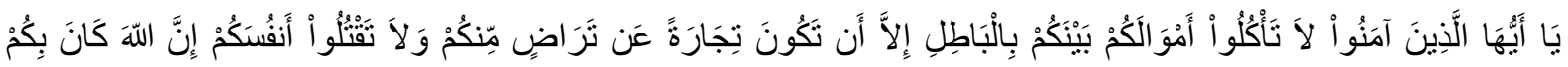


رَحِيمًا

O you who have believed, do not consume one another's wealth unjustly but only [in lawful] business by mutual consent. And do not kill yourselves [or one another]. Indeed, Allah is to you ever Merciful $(1,4: 29)$.

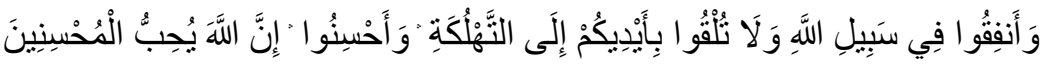

"Spend for God's sake, yet do not expose yourselves to ruin through your own hands" (16, 2:195).

According to Islam suicide is forbidden and a great sin which is not forgivable. Its doer will be punished heavily in the afterworld. It is a major sin (18). A Muslim has no right to take his own life, no matter the circumstances. The Prophet taught that anyone who commits suicide will dwell in eternal hell fire, adding that Allah will punish him with the means that which he used to commit suicide. It was narrated from Abu Hurayrah (may Allah be pleased with him) that the Prophet (blessings and peace of Allah be upon him) said: "Whoever throws himself down from a mountain and kills himself will be throwing himself down in the Fire of Hell forever and ever (Abu \& Isma'il, 2016).

Whoever drinks poison and kills himself will be sipping it in the Fire of Hell for ever and ever. Whoever kills himself with a piece of iron will have that iron in his hand, thrusting it into his belly in the Fire of Hell forever and ever." In another related hadith, the Prophet (s.a.w) said: "Whoever kills himself with something will be punished with it on the Day of Resurrection (Abu \& Isma'il, 2016).

\section{Conclusion}

Although euthanasia may be viewed and accepted as a legal solution in medical fields for alleviating pain and suffering to gravely ill patients and their families, it creates numerous dilemma among various societies. Quran absolutely rejects this phenomenon in all its forms and views it as a violation of human rights as well as an infringement to God's willing and His Commands.

\section{Recommendation}

More studies and researches are recommended to shed light on numerous perspectives of euthanasia and its applications in Quran verses.

\section{References}

Abu, A. M., \& Isma'il, al-Bukhari. (2016). Suicide - The Islamic Stance from Qur'an and Sunnah. Sep 29, 2016 - (Bukhari 5700; Muslim 110) ... (Bukhari Book 70 Hadith 575).

Bible. First Thessalonians 5:23.

Bilal, S. H., \& Badr, N. (2013). Legal and Ethical issues of Euthanasia. Middle East Journal of Nursing, 6(4).

Geritt, K. K., \& Br J. Psychiatry. (2017). When unbearable suffering incites psychiatric 


\section{Macrothink \\ Issues in Social Science \\ ISSN 2329-521X 2020, Vol. 8, No. 1}

patients to request euthanasia. British Journal of Psychiatry, 211(4), 238-245. PMID: 28970302.

Darmian, L. C. (2009). Euthanasia is there a case? The South African Journal of Bioethics and Law, 2(1).

Man is an owner of his taught, actions, life and existence and will. Published online 2016 Dec 1. PMCID: PMC5300707.

Ian, D. (2003). A Merciful End: The Euthanasia Movement in Modern America.

Jesse, O. (2015). Freewill: The degree of freedom Within, July, 2015.

McMaster University. Hippocratic Oath.

Merriam-webster.com > dictionary > martyrdom.

Micheal, C. (1961). Avon Book Devision, p. 316.

Nargus, E. (2012). The ethics of Euthanasia. Australian Medical Student Journal.

quran anhar.ir, Chapter4, verses 29-30.

Standford Encyclopedia of Philosophy, Aug21, 2015.

Suicide. Standford Encyclopedia of Philosophy.

Translation of Sahih Muslim, Book: 22.

\section{Copyright Disclaimer}

Copyright for this article is retained by the author(s), with first publication rights granted to the journal.

This is an open-access article distributed under the terms and conditions of the Creative Commons Attribution license (http://creativecommons.org/licenses/by/3.0/). 